\title{
POLA MAKAN BALITA STATUS GIZI KURANG DI PUSKESMAS CIUMBULEUIT CIDADAP BANDUNG
}

\author{
SKRIPSI \\ Diajukan untuk Memenuhi Sebagian Syarat Memperoleh Gelar Sarjana \\ Pendidikan Program Studi Pendidikan Tata Boga
}

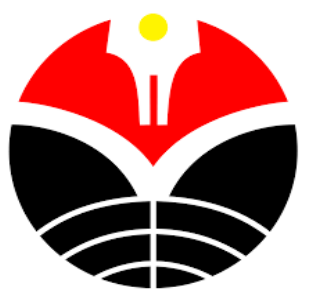

Oleh

Sana Widianti

NIM 1506314

PROGRAM STUDI PENDIDIKAN TATA BOGA DEPARTEMEN PENDIDIKAN KESEJAHTERAAN KELUARGA FAKULTAS PENDIDIKAN TEKNOLOGI DAN KEJURUAN UNIVERSITAS PENDIDIKAN INDONESIA 2019 


\title{
POLA MAKAN BALITA STATUS GIZI KURANG DI PUSKESMAS CIUMBULEUIT CIDADAP BANDUNG
}

Oleh

Sana Widianti

NIM. 1506314

Sebuah Skripsi diajukan untuk salah satu syarat memperoleh gelar sarjana Pendidikan Program Studi Pendidikan Tata Boga Departemen PKK FPTK UPI

\author{
CSana Widianti 2019 \\ Universitas Pendidikan Indonesia
}

Desember 2019

Hak cipta dilindungi undang-undang.

Skripsi ini tidak boleh diperbanyak seluruhnya atau sebagian, dengan dicetak ulang, difoto kopi atau cara lainnya tanpa izin penulis 


\section{LEMBAR PENGESAHAN}

SANA WIDIANTI

\section{POLA MAKAN BALITA STATUS GIZI KURANG DI PUSKESMAS CIUMBULEUIT CIDADAP BANDUNG}

disetujui dan disahkan oleh pembimbing :

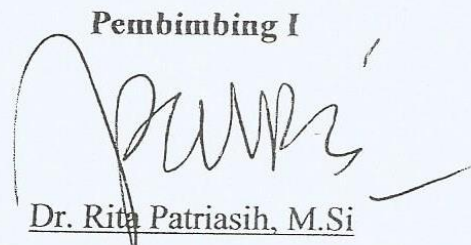

NIP 197008111998022002

Pembimbing II

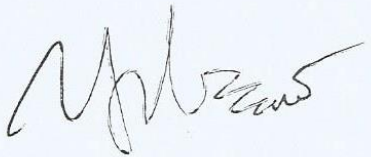

Dr. Cica Yulia, M.Si

NIP 198007012005012001

Mengetahui,

Ketua Departemen Pendidikan Kesejahteraan Keluarga

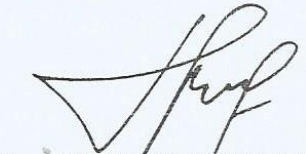

Dra. Hj. Spi Subekti, M.Pd

NIP 195909281985032001 
POLA MAKAN BALITA STATUS GIZI KURANG DI PUSKESMAS CIUMBULEUIT

CIDADAP BANDUNG

Sana Widianti, Rita Patriasih, Cica Yulia

Program Studi Pendidikan Tata Boga, Departemen Kesejahteraan Keluarga, Fakultas

Pendidikan Teknologi dan Kejuruan, Universitas Pendidikan Indonesia

Sanawidianti123@gmail.com

\begin{abstract}
ABSTRAK
Gizi kurang adalah gangguan kesehatan akibat kekurangan atau ketidakseimbangan zat gizi yang diperlukan untuk pertumbuhan. Faktor langsung penyebab gizi kurang adalah makanan yang dikonsumsi tidak memenuhi jumlah dan komposisi zat gizi yang memenuhi syarat gizi seimbang. Tujuan penelitian ini untuk mengetahui pola makan anak balita berstatus gizi kurang yang tercatat di puskesmas Ciumbuleuit Cidadap Bandung. Metode yang digunakan deskriptif kuantitatif dengan desain Cross-Sectional. Populasi sebanyak 70 orang ibu yang memiliki anak balita status gizi kurang. Teknik pengambilan sampel adalah purposive dengan pertimbangan anak balita yang memiliki status gizi kurang berusia 4-5 tahun sudah menjadi konsumen aktif. Sampel dalam penelitian ini adalah 20 orang ibu balita gizi kurang. Penelitian diperoleh lebih dari setengahnya (55\%) balita makan hanya dua kali dalam sehari dan mengkonsumsi snack sebanyak dua kali. Jadwal makan anak balita sebagian besar $(77,5 \%)$ tidak teratur. Kuantitas makan balita seluruhnya masih belum sesuai dengan yang dianjurkan. Rata-rata konsumsi makanan pokok 177,9 gram, lauk hewani 48,4 gram, lauk nabati 9,75 gram, sayuran 32,7 gram, buah 11,6 gram, susu 32,8 gram. Kualitas makan balita sebagian besar( $85 \%)$ defisit energi, lebih dari setengahnya $(70 \%)$ defisit protein, sebagian besar (95\%) defisit lemak, lebih dari setengahnya (75\%) defisit karbohidrat, dan variasi makanan balita sebagian besar $(77,5 \%)$ tidak bervariasi. Rekomendasi bagi lembaga terkait diharapkan untuk memberikan pengetahuan dan pendampingan untuk pola makan pada balita status gizi kurang, bagi ibu balita memperhatikan makanan yang dikonsumsi oleh anak sehingga akan menghasilkan pola makan yang baik.
\end{abstract}

Kata Kunci : anak bawah lima tahun, pola makan, status gizi kurang 


\title{
EATING HABITS OF TODDLER WITH UNDERWEIGHT STATUS IN PUSKESMAS CIUMBULEUIT CIDADAP BANDUNG

\author{
Sana Widianti, Rita Patriasih, Cica Yulia
}

\author{
Study Program Of Culinary, Education Home Economic Education Department, \\ Faculty of Technology of Vocational Education, Indonesian University of Education \\ Sanawidianti123@gmail.com
}

\begin{abstract}
Underweight is a health disorder which is caused by the deficiency or imbalance of nutrients needed for growth. The direct factor of underweight was the food consumed not meet the need of qualified nutrients Balanced nutrient. The research was aimed to find out children's diet recorded in Puskesmas Ciumbuleuit Cidadap Bandung. The method of this research was quantitative descriptive with CrossSectional design. The population of was 70 mothers who have of toddlers underweight status. The sampling technique used was purposive in consideration of toddlers with a underweight status of was 4 to 5 years old since they were already active consumers therefore the sample of this research was 20 people. The results of research showed that $55 \%$ of toddlers was only eating and snacking twice a day, $77,5 \%$ of toddlers feeding schedule was irregular, the quantity of toddler eating did not meet daily nutrition needs since the average intakes of staple food was 177.9 grams, 48.4 grams of animal side dishes, 9.75 grams of vegetable side dishes, 32.7 grams of vegetables, 11.6 grams of fruit, 32.8 grams of milk, 20 grams of oil, and 34 grams of sugar, the quality of $85 \%$ of toddler feeding was energy deficit, $70 \%$ of them were protein deficit $95 \%$ was fat deficit, $77,5 \%$ of toddler eating variation was not varied, and a 77,5\% of toddler eating variation was not varied. Recommendations for related institutions are expected to provide knowledge and mentoring to the diet in toddlers underweight status, for mothers of toddlers pay attention to food consumed by children so that it will produce a good diet.
\end{abstract}

Keywords: eating habits, toddler, underweight status 


\section{DAFTAR ISI}

LEMBAR PENGESAHAN ........................................................................... i

LEMBAR KEASLIAN SKRIPSI .......................................................... ii

KATA PENGANTAR ..................................................................................... iii

UCAPAN TERIMAKASIH .................................................................. iv

ABSTRAK ............................................................................................................. vi

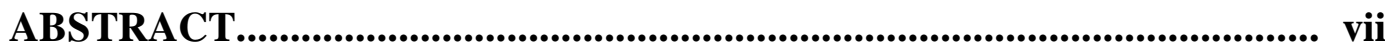

DAFTAR ISI ........................................................................................ viii

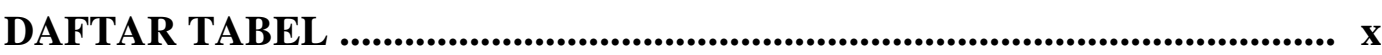

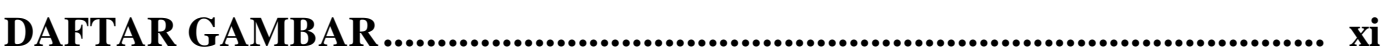

BAB 1 PENDAHULUAN ........................................................................ 1

1.1 Latar Belakang Penelitian..................................................................... 1

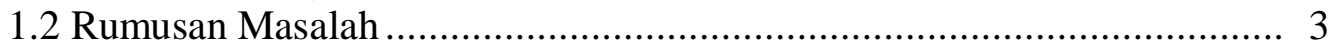

1.3 Tujuan Penelitian ..................................................................... 3

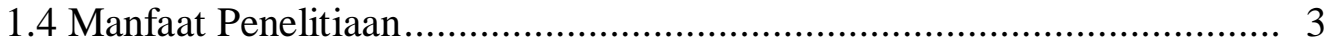

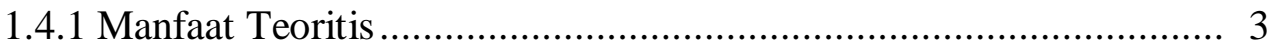

1.4.2 Manfaat Praktis ....................................................................... 3

1.5 Struktur Organisasi Skripsi ........................................................... 3

BAB II TINJAUAN PUSTAKA ................................................................... 5

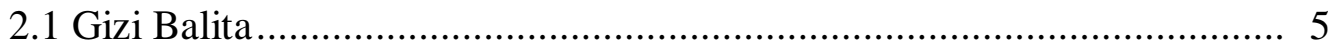

2.1.1 Usia 1-3 Tahun (Toodler) .......................................................... 5

2.1.2 Usia Pra Sekolah ................................................................... 5

2.1.3 Kecukupan Zat Gizi Balita ........................................................... 6

2.1.4 Indikator Pengukuran Status Gizi Kurang Balita....................... 12

2.2 Status Gizi Kurang Balita ................................................................... 13

2.2.1 Faktor Status Gizi Kurang .................................................... 13

2.2.2 Pencegahan Status Gizi Kurang ............................................ 14

2.3 Pola Makan Balita Terhadap Status Gizi ............................................ 15

2.3.1 Faktor yang Mempengaruhi Pola Makan ................................... 15

2.3.2 Indikator Pola Makan .............................................................. 17

2.3.3 Survei Konsumsi ................................................................... 21

2.4 Penelitian Terdahulu .................................................................... 23

BAB III METODE PENELITIAN _..................................................... 26

3.1 Desain Penelitian............................................................................... 26

3.2 Partisipan dan Tempat Penelitian.......................................................... 26

3.2.1 Partisipan ................................................................................... 26

3.3 Populasi dan Sampel ...................................................................... 26

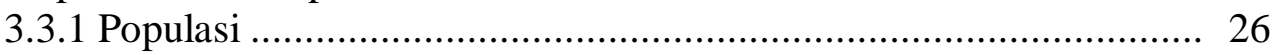

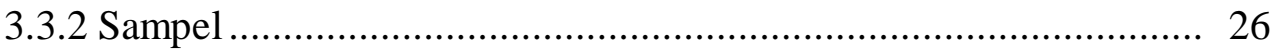

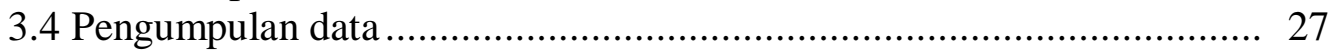

3.4.1 Teknik Pengumpulan Data .................................................. 27

3.4.2 Instrumen Penelitian............................................................. 27

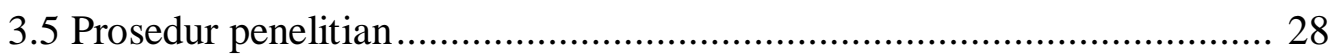

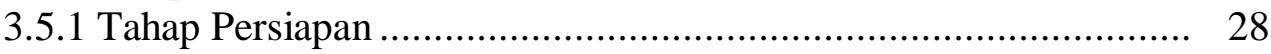


3.5.2 Tahap Pelaksanaan Penelitian.................................................... 28

3.5.3 Tahap Penyusunan Laporan Penelitian ...................................... 28

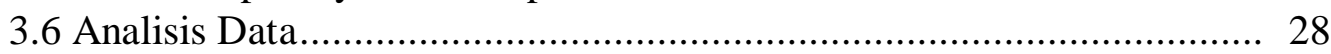

3.6.1 Data Food Frequency Questionnaire ..................................... 28

3.6.2 Data Food Recall .................................................................. 29

3.6.3 Skala Guttman.................................................................. 29

BAB IV TEMUAN DAN PEMBAHASAN............................................... 31

4.1 Frekuensi Makan Balita................................................................ 32

4.5 Jadwal Makan Balita ...................................................................... 41

4.2 Kuantitas Makan Balita .................................................................... 43

4.3 Kualitas Makan Balita .................................................................... 46

4.4 Variasi Makan Balita.......................................................................... 50

BAB V_SIMPULAN, IMPLIKASI, DAN REKOMENDASI..................... 54

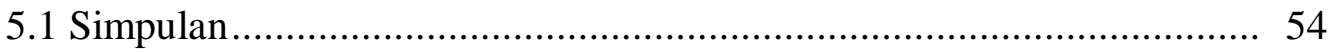

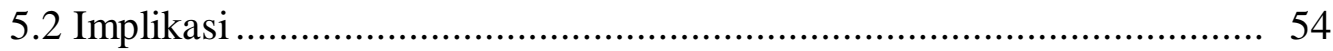

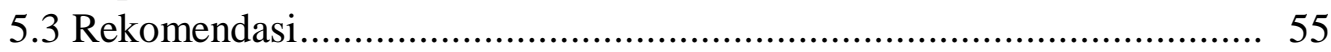

DAFTAR PUSTAKA .......................................................................................... 56

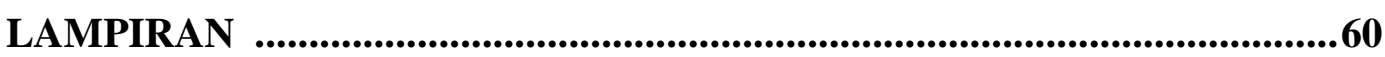




\section{DAFTAR PUSTAKA}

Adriani, Merryana. 2016. Peranan Gizi dalam Siklus Kehidupan. Jakarta : Prenada Media Group

Adriani, Merryana. 2016. Pengantar Gizi Masyarakat. Jakarta : Prenada Media Group

Aidina, Chintya Nurul. dkk. (2015). Pola Makan, Kecukupan Gizi dan Status Gizi Balita Pada Keluarga Miskin di Perumnas Manddala, Kelurahan Kenangan Baru. Departemen Gizi Kesehatan Masyarakat FKM USU/Vol 1 No 5

Ana, Vilda dan Eko Hartini. 2018. Buku Ajar Dasar Ilmu Kesehatan. Sleman: Deepublish

Arifin, Zainul. (2015). Gambaran Pola Makan Anak Usia 3-5 Tahun dengan Gizi Kurang di Pondok Bersalin Trisakti Balong Tani Kecamatan Jabon-Sidoarjo.

Midwiferia/vol;1No;1?April 2015

Asydhad, Lia Amalia dan Mardiah. 2006. Makanan Tepat Untuk Balita Plus Resep Makanan. Depok : Kawan Pustaka

Bulan Febry, Ayu dan Zulfito Marendra. (2014). 101 Menu MPASI Sehat. Jakarta :PandaMedia

Chandra, ery. 2019. Malnutrisi Ancam Anak-anak Indonesia di Jawa Barat Kasus Kekurangan Gizi Hampir 30 Persen. Tersedia di http://jabar.tribunnews.com/2019/02/12/malnutrisi-ancam-anak-anak indonesia-di-jawabarat-kasus-kekurang-gizi-hampir-30-persen . diakses pada 26 Maret 2019

Cindy, bulan Putri Insan Raissa. dkk. (2015). Hubungan Konsumsi Mie Instan dengan Status Gizi pada Balita 24-59 bulan di Desa Jamus Kecamatan Mranggen Kabupaten Demak, Indonesia Tahun 2015. Jurnal Kesehatan Masyarakat (e-Journal) /Volume 4, Nomor 2, April 2016

Damanik, Hamonangan. (2013). Hubungan Pola Makan dengan Status Gizi Pada Balita Usia 1-4 Tahun di Lingkungan II Kelurahan Namogajah Medan Tahun 2013. Jurnal Ilmiah Keperawatan Imelda/ Vol. 1, No. 1, Februari 2015

Dejesetya. 2016. Pola Konsumsi Sayur dan Buah Anak Usia 4-6 Tahun Pada Masyarakat Pesisir Desa Randusanga Kulon Brebes. Fakultas Ilmu Pendidikan Universitas Negeri Semarang

Dio, Giovani Prasati. 2019. Banyak Masalah Gizi Jadi Tantangan Indonesia. tersedia di https://www.liputan6.com/health/read/3874200/banyak-kasusmasih-jadi-tantangan-di-indonesia . diakses pada 27 Maret 2017 turun-masalah-gizi-

\section{6}

Sana Widianti, 2020

POLA MAKAN BALITA STATUS GIZI KURANG DI PUSKESMAS CIUMBULEUIT CIDADAP BANDUNG

Universitas Pendidikan Indonesia | repository.upi.edu | 
Emawati, Fitrah. Dkk. 2016. Gambaran Konsumsi Protein Nabati dan Hewani Pada Anak Balita Stunting dan Gizi Kurang di Indonesia. Penelitian Gizi dan Makanan Desember 2016 Vol. 39 (2): 95-102

Fajrlan. 2018. Gizi Buruk dan Penyakit Tidak Menular Hantui 2019. Tersedia di https://www.cnnindonesia.com/gaya-hidup/20181228120411-255356988/gizi -burukdan-penyakit-tidak-menular-hantui-2019. diakses pada 27 Maret 2019

Fitriyani. 2018. Ini Alasan Anak Perlu Makan Ikan Dua Kali Seminggu. Tersedia di https://id.theasianparent.com. Diakses pada 21 November 2019

Fitrianingsih dan Suesti. (2009). Hubungan Kebiasaan Makan Balita dengan Status Gizi Balita Usia 1-5 Tahun Di Posyandu Kasih Ibu Desa Ngentakrejo Lendah Kulon Progo Tahun 2009.

Gardjito, Murdijati. (2014). Pendidikan Konsumsi Pangan. Jakarta: Kencana

Handayani, Khoiri fury. 2014. Gambaran Konsumsi Makanan Pada Anak Usia Toddler yang Mengalami Gizi Kurang di Kecamatan Balerejo Kabupaten Madiun. Fakultas Ilmu Kesehatan Universitas Muhamadiyah Surakartaa

Hanifah, Erma. (2011). Cara Hidup Sehat. Jakarta : PT Balai Pustaka

Hardiman, Intarina. dkk. (2014). Menu Karbohidrat Bayi dan Balita. Jakarta : PT Gramedia Pustaka Utama

Isnaini, Nurul, dkk. (2016). "Hubungan Antara Pola Asuh, Pola Makan, dan Penyakit Interfeksi Terhadap Kejadian Gizi Buruk Balita di Kabupaten Magetan”. Fakultas Ilmu Kesehatan Universitas Muhamadiyah Surakarta

Jusup, Lenny. (2013). 50 Resep Makanan Peningkat Daya Tahan Tubuh Bayi \& Balita. Jakarta : Gramedia Pustaka Utama

Kamila, Li, dkk. (2018). Konseling Tentang Pola Asuh Makan Sebagai Upaya Mengubah Pengetahuan Ibu Yang Memiliki Balita Gizi Kurang. Jurnal Bidan "Midwife Journal" Vol 5 No 1 (januari, 2018)

Kementetian Kesehatan RI. 2014. Pedoman Gizi Seimbang. Jakarta

Khomsan, Ali dan Faisal Anwar. 2008. Sehat Itu Mudah. Bandung : Mizan

Marhamah, dkk. (2014). Perilaku Konsumsi dan Status Gizi Anak Sekolah Dasar di Kota Serang.Jurnal matematika, sains dan teknologi. Volume 15, Nomor 2, September 2014, 97-105

Marista, Adelia Safitri. 2018. Masalah Gizi di Indonesia. tersedia di https://hellosehat.com/hidup-sehat/nutrisi/masalah-gizi-di-indonesia/ . diakses pada 26 Maret 2019 
Sugiono. (2015) Metode Penelitian Pendidikan. Bandung : Alfabeta

Nasution, Henna Sultana.dkk, (2018). Hubungan Pola Makan dengan Status Gizi Pada Anak Balita di Wilayah Kerja Puskesmas Medan Sunggal di Lingkungan XIII Kelurahan SunggalKecamatan Medan Sunggal Tahun 2018.Jurnal kesehatan masyarakat dan lingkungan hidup. ISSN 2528-4002

Nurul Aidina, Chintya, dkk. (2015). Pola Makan, Kecukupan Gizi, dan Status Gizi Balita Pada Keluarga Miskin di Perumnas Mandala, Kelurahan Kenangan Baru.

Nurtina, Wa Ode, dkk. (2017). Faktor Resiko Kejadian Gizi Kurang Pada Balita di Wilayah Kerja Puskesmas Benu-benua Kota Kendari. J.AMPIBI 2(1) hal. (21-27) Februari 2017

Pandi, Emma dan Wirakusumah. 2012. Panduan Lengkap Makanan Balita. Jakarta: Penebar Swadaya Grup

Ramie, Agustin dan Tri Aulia Rahma. (2016). Pola Makan Anak Umur 3-5 Tahun yang Mengalami Gizi Kurang. Seminar dan workshop Nasional Keperawatan "Implikasi Paliatif pada Bidang Kesehatan"

Rohmah, Iftitakhur. (2018). Hubungan Partisipasi Ayah dengan Praktik Ibu dalam Pemberian Makan Balita (Jenis, Jumlah, Jadwal). Fakultas Keperawatan Universitas Airlangga. Surabaya

Septikasari, Majestika. (2018). Status Gizi Anak dan Faktor yang Mempengaruhi. Yogyakarta : UNY Press

Sirajuddin. (2018). Survey Konsumsi Pangan. TK: Kementrian Kesehatan Republik Indonesia

Soenardi. 2005. Variasi Makanan Balita. Jakarta : Duta Prima

Subarkah, Toni, dkk. 2016. Pola Pemberian Makan Terhadap Status Gizi Pada Anak Usia 1-3 Tahun. INJEC Vol.1 No.2

Supriasa, dkk. 2002. Penilaian Status Gizi. Jakarta : EGC

Sutomo, Budi dan Dwi Yanti Anggraini. 2010. Menu Sehat Alamiuntuk Batita \& Balita. Jakarta : PT AgroMedia Pustaka

Triandhini, Retno, Angkit Kinasih, Anik Sriwijayanti. 2018. Konsumsi Tinggi Lauk Hewani, Rendah Sayur dan Rendah Aktivitas Fisik Berhubungan dengan Kejadian Berat Badan Pada Anak Sekolah Dasar. Jurnal Gizi Indonesia (The Indonesian Journal of Nutrition), $6(2)$

Utari, Hermina Pratiwi, Deny Yudi Fitriani. 2017. Hubungan Status Gizi dan Kebiasaan Minum Minuman Ringan dengan Kejadian Menarce Dini. Journal of Nutrition College Volume 6, Nomor 1, Tahun 2017, Halaman 113-118 
Waladow, Geiby. dkk. (2013). Hubungan Pola Makan dengan Status Gizi Pada Anak Usia 35 Tahun di Wilayah Kerja Puskesmas Tompaso Kecamatan Tompaso. Ejournal Keperawatan (e-Kp)/Volume 1, nomor 1, Agustus 2013

Wijaya, Jusma Kusuma Geswar. 2017. Hubungan Pola Makan dan Status Gizi Terhadap

Tinggi Badan Mahasiswa Pendidikan Dokter Fakultas Kedokteran Universitas Hasanudin Angkatan 2017. Fakultas Kedokteran, Universitas Hasanudin 